\title{
Application of Statistical Modeling and Hypothesis Testing to Reinforce Model Validation Concepts in Bioprocess Control Laboratory
}

\author{
Laxmikant Patil ${ }^{1}$, Gururaj Bhadri ${ }^{2}$, Shivalingsarj Deasi ${ }^{3}$, Anil Shet ${ }^{4}$, Veeresh Hombalimath ${ }^{5}$ \\ 1,3,4,5 Department of Biotechnology, KLE Technological University, Hubballi - 31 \\ ${ }^{2}$ Department of Mathematics, KLE Technological University, Hubballi - 31 \\ lrpatil@kletech.ac.in, gnbhadri@kletech.ac.in, desaisv@kletech.ac.in, \\ anil_shet@kletech.ac.in, hombalimath@kletech.ac.in
}

\begin{abstract}
Bio-Process Control is the application of automatic control in the field of Biotechnology. The course emphasizes on the dynamic behaviour, physical and empirical modeling of bio-systems and advanced control strategies. The primary objective of process control is to maintain a process at the desired operating conditions with quality standards in an economic way and with safety aspects in place. In this backdrop, the present study was implemented as an exercise and structured inquiry experiments in Bioprocess Control Laboratory for VI semester undergraduate students of Biotechnology engineering. The course was hitherto taught in a conventional approach with analysis and interpretation of dynamic responses of different systems with standard inputs. The delivery of the exercise was implemented in three phases namely training, execution and assessment phase. In the present study dynamic response of control system was predicted with models and then compared with experimental observations. The resulting deviations therein, were analyzed for the possible underlying reasons and a chisquare goodness of fit test was performed to validate the model. The assessment of the students' performance was done on individual basis through a Rubrics-based approach and attainment of the Program outcomes addressed was recorded which ranged from $80-95 \%$. The study helped in addressing the graduate attributes related to the investigation of complex problem, analyze the correlation of the experimental outcomes with underlying theoretical concepts and interpretation of results. A formal feedback from the students revealed that the active learning approach enhanced the understanding of the control engineering concepts through the application of statistical modeling and analysis.
\end{abstract}

\section{Laxmikant Patil}

Department of Biotechnology, KLE Technological

University, Hubballi - 580031, India

lrpatil@kletech.ac.in

Keywords: Bio-Process Control, statistical methods, Hypothesis testing, Chi-square goodness of fit test, Model validation, Regression analysis

\section{Introduction}

Process control has become increasingly important in the process industries as a consequence of global competition, rapidly changing economic conditions, and more stringent environmental and safety regulations. Process control and its allied fields of process modeling \& optimization are critical in the development of more complex processes for manufacturing high-value-added products. With the advent of computer-based process control systems it is possible to operate modern plants safely and profitably without compromising on product quality and environmental requirements. This underscores the scope of process control in smart manufacturing technology (Manufacturing 4.0). Consequently, biotechnologists and process engineers need to master this subject to be able to design and operate modern plants. The emphasis on product quality in manufacturing (e.g., six sigma) has increased the reliance on monitoring techniques such as statistical process control (Eutimio Gustavo Fernandez. et al.,2013; Sharanappa, A. et al.,2018; Sharanappa, A. et al.,2020; Romero R.et al.,1995)

The control systems can be represented with a set of mathematical equations known as mathematical models. These models are helpful in design and analysis of control systems. In control engineering, a transfer function (system function) of a system is a mathematical function which theoretically models the system's output for each possible input. The advantage of transfer function analysis is that the output of a system can be easily determined for any possible change in input parameter.

Statistics is applied throughout the life of a process control scheme - for assessing its economic advantage, designing inferential properties, identifying dynamic models, monitoring performance and diagnosing faults. The statistics deals with the collection, presentation, analysis and use of data to make decisions, solve problems and design products and processes. Methods and techniques in statistics help control engineers to make a consistent quality product, detect problems, understand phenomena subject to variation, and predict systems (Kwang-Min Lee. et al.,2006; Dahms, A.S.et al.,2001).

A statistical hypothesis is an assumption about a population parameter. Hypothesis testing refers to the formal 
procedures used to accept or reject hypotheses based on statistical evidence. The best way to determine whether the hypothesis is true or not would be to examine the entire population. Since that is often impractical, researchers typically examine a random sample from the population and then decide whether the hypothesis is to be rejected or not (Douglas Montgomery et al., 2014).

A mathematical model is an abstract model that uses mathematical concepts and language to describe the behaviour of a system. It helps to understand and explore the meaning of equations or functional relationships. A model may help to explain a system and to study the effects of different components, and to make predictions about behaviour. Model validation is the process of confirming that, the outputs of a model are acceptable with respect to the experimental data generated. They play a pivotal role in simulation and prediction, that can act as baseline data for controlling and refining the process parameters.

The objective of study was to improve the ability of students to analyze the data, validate the model, interpret the results, in context of Control Engineering problems by incorporating statistical approach. This study was carried out in Bioprocess Control Engineering laboratory for VI semester undergraduate students of Biotechnology Engineering.

\section{Methods}

\section{A. Design of Bioprocess Control Laboratory}

The Bioprocess Control Laboratory was designed taking into consideration of inputs from industry stake-holders. The Laboratory experiments were categorized into four categories (Demonstration, Exercise, Structured Enquiry and Open Ended Experiment). Accordingly, the present study was a part of exercise and structured enquiry experiments wherein reinforcement of model Validation Concepts and Hypothesis Testing was performed (Sharnappa A.et al.,2020; Zaiton Haron. et al.,2013; Anil Shet.et al,2017). The program outcomes addressed through this activity are PO-4 (Conduct Investigation of complex problems: Use research-based knowledge \& research methods including design of experiments, analysis and interpretation data, and synthesis of information to provide valid conclusions), PO-10 (Communication: Communicate effectively on complex engineering activities with the engineering community and with the society at large, such as being able to comprehend and write effective reports and design documentation, make effective presentation and give $\&$ receive clear instructions), PSO-1 (Good Laboratory Practices-GLP: Demonstrate adequate proficiency of good laboratory practices in terms of accuracy \& precision, safety, ethics and reproducibility and able to follow Standard Operating Procedures-SOP).

\section{B. Implementation of the Laboratory}

The present study was conducted for VI semester undergraduate students of engineering in Biotechnology for Bioprocess Control Laboratory.

About the Laboratory: The laboratory comprises response of different control systems to standard inputs, wherein a suitable mathematical model was developed and prediction of theoretical response was compared with the experimental observations. The resulting deviations therein, were analyzed for the possible underlying reasons and a Chisquare goodness of fit test was performed to validate the model. The laboratory includes of basic understanding of the control systems used in various bio-processes, study of dynamic/transient response of first order single and multicapacity processes (connected in interacting and noninteracting mode) for various standard inputs. The observed Step and Impulse response of single and multi-capacity systems in different modes (Interacting \& Non-Interacting) was compared with mathematically predicted response. Transient response of different Control systems (Temperature, Pressure \& Flow control systems) using different controllers such as P, PI, PD and PID for Servo and Regulatory mechanism control problems was studied.

Modus Operandi of implementation:

The Bioprocess Control Engineering Laboratory was executed in three modules as represented in Figure.1.

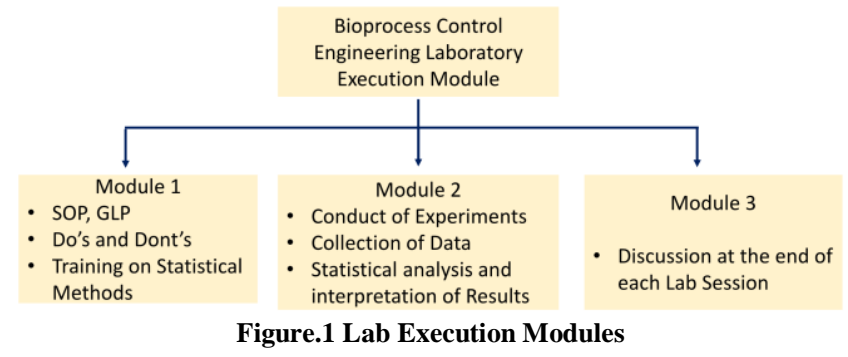

Module-1: Students were trained on

- Standard Operating Procedures (SOP) of different process control equipments like temperature control trainer, Pressure control trainer, Flow control trainer, Single capacity system, Interacting\& Non Interacting systems.

- Training on Statistical methods/techniques such as Curve Fitting/regression analysis, Hypothesis testing was conducted.

Module-2: All laboratory experiments were conducted and analysis of the data was performed using statistical methods like Correlation, Regression \& Hypothesis testing (Chi Square Test for Goodness of fit).

Module-3: Discussion-based teaching at the end of each Lab Session: Discussion-based teaching is an instructional approach that prioritizes learner acquisition of knowledge, skills, and attitudes through discourse rather than passive approaches that focus on lecture, reading, or viewing. Discussion based teaching method stimulate critical thinking in students and challenge them to think more deeply and to 
articulate their ideas. The main objective of the discussion is to get students to practice thinking about the course material and bring clarity about the conceptual applications of Correlation, Regression, Hypothesis testing, model validation in process control course.

Discussion points/questionnaire at the end of each Lab session:

a. Comment on the results obtained.

b. Whether experimentally observed response tallies with theoretically predicted response? Yes /No

c. If No, then Enlist at least three reasons for deviations between Observed and predicted response.

d. Importance of Assumptions during modeling and its impact on predictions.

e. Whether deviations between observed \& experimental results are due to one or more of following:

f. Assumptions made during model building (Linear assumptions, Linearization of Non-Linear systems),

g. Experimental errors

h. Why do we need to validate mathematical model?

\section{Assessment}

A. Assessment of Experiments

Rubrics-based assessment was followed for all the experiments of Bioprocess Control Laboratory as per the assessment rubrics shown in the Table 1.

Table 1: Rubrics used for assessment of Exercise and Structured Enquiry Experiments

\begin{tabular}{|l|l|}
\hline $\begin{array}{l}\text { Rubrics parameter: Selection of Procedure } \\
\text { PI- code addressed: 4.1.2 }\end{array}$ \\
\hline $\begin{array}{l}\text { Inadequate } \\
\text { (up to 25\%) }\end{array}$ & $\begin{array}{l}\text { Demonstrate little or no ability to } \\
\text { conduct experiments. Did not collect } \\
\text { Meaningful data. }\end{array}$ \\
\hline $\begin{array}{l}\text { Average (up } \\
\text { to 50\%) }\end{array}$ & $\begin{array}{l}\text { Demonstrate some ability to conduct } \\
\text { experiments. Collected some } \\
\text { Meaningful data. }\end{array}$ \\
\hline $\begin{array}{l}\text { Good (up to } \\
\text { 75\%) }\end{array}$ & $\begin{array}{l}\text { Demonstrate adequate ability to } \\
\text { conduct Experiments. Collected most } \\
\text { of the needed data. }\end{array}$ \\
\hline $\begin{array}{l}\text { Outstanding } \\
\text { (up to 100\%) }\end{array}$ & $\begin{array}{l}\text { Demonstrate superior ability to conduct } \\
\text { experiments. } \\
\text { appropriate data. }\end{array}$ \\
\hline $\begin{array}{l}\text { Rubrics parameter: Conduct of experiment } \\
\text { PI- code addressed: } 4.1 .3\end{array}$ \\
\hline $\begin{array}{l}\text { Inadequate } \\
\text { (up to 25\%) }\end{array}$ & $\begin{array}{l}\text { Inadequate quality of experimental } \\
\text { work. No proper demonstrations of } \\
\text { team work and SOP. }\end{array}$ \\
\hline $\begin{array}{l}\text { Average (up } \\
\text { to 50\%) }\end{array}$ & $\begin{array}{l}\text { Experiments were conducted. But team } \\
\text { work and SOP need to be effective. }\end{array}$ \\
\hline $\begin{array}{l}\text { Good (up to } \\
\text { 75\%) }\end{array}$ & $\begin{array}{l}\text { Adequate conduct of experiment. Team } \\
\text { work demonstrated however, SOP need } \\
\text { to be strengthened. }\end{array}$ \\
\hline
\end{tabular}

\begin{tabular}{|l|l|}
\hline $\begin{array}{l}\text { Outstanding } \\
\text { (up to 100\%) }\end{array}$ & $\begin{array}{l}\text { Proper conduct of experiment. } \\
\text { Demonstration of team work and } \\
\text { followed SOP. }\end{array}$ \\
\hline
\end{tabular}

Rubrics parameter: Correlate the experimental outcomes with underlying theoretical concepts and principles

PI- code addressed: 4.1 .4

\begin{tabular}{|l|l|}
\hline $\begin{array}{l}\text { Inadequate } \\
\text { (up to 25\%) }\end{array}$ & $\begin{array}{l}\text { Did not correlate the experimental } \\
\text { Outcomes with underlying theoretical } \\
\text { concepts and principles. }\end{array}$ \\
\hline $\begin{array}{l}\text { Average (up } \\
\text { to 50\%) }\end{array}$ & $\begin{array}{l}\text { Correlated experimental outcomes with } \\
\text { underlying theoretical concepts and } \\
\text { principles but with few mistakes. }\end{array}$ \\
\hline $\begin{array}{l}\text { Good (up to } \\
\text { 75\%) }\end{array}$ & $\begin{array}{l}\text { Correlated few experimental outcomes } \\
\text { with underlying theoretical concepts } \\
\text { and principles without any mistakes }\end{array}$ \\
Outstanding \\
(up to 100\%)
\end{tabular} \begin{tabular}{l}
$\begin{array}{l}\text { Correlated all the experimental } \\
\text { outcomes with underlying theoretical } \\
\text { concepts and principles without any } \\
\text { mistakes. }\end{array}$ \\
\hline
\end{tabular}

Rubrics parameter: Data Collection \& representation PI- code addressed: 4.3 .1

Inadequate $\quad$ Raw data, including units, are not (up to 25\%) recorded in a way that is appropriate and clear. Data representation is not according to the format and not at all clear for analysis.

Average (up Raw data, including units, are recorded to $50 \%$ ) although not as clearly or appropriately as they might be. Data representation is as per the format with some logical error and not clear for analysis.

Good (up to Raw data, including units, are recorded. 75\%) $\quad$ Data representation is as per the format \begin{tabular}{l|l} 
& and not so clear for analysis. \\
\hline Outstanding & Raw data, including units, are recorded
\end{tabular} (up to 100\%) appropriately. Data representation is as per the format and clear for analysis.

Rubrics parameter: Data Analysis and interpretation PI- code addressed: 4.3 .2

\begin{tabular}{|l|l|}
$\begin{array}{l}\text { Inadequate } \\
\text { up to 25\%) }\end{array}$ & $\begin{array}{l}\text { Statistical methods were completely } \\
\text { misapplied or absent. } \\
\text { The results are neither interpreted in a } \\
\text { logical and proper way nor compared } \\
\text { with literature values. The limitations } \\
\text { and weaknesses are not discussed, nor } \\
\text { are suggestions made as to how to limit } \\
\text { or eliminate them. }\end{array}$ \\
\hline $\begin{array}{l}\text { Average (up } \\
\text { to 50\%) }\end{array}$ & $\begin{array}{l}\text { Few Statistical methods were } \\
\text { attempted. } \\
\text { The results are interpreted and } \\
\text { compared with literature values, but not } \\
\text { clear. The limitations and weaknesses } \\
\text { are discussed with no suggestions }\end{array}$ \\
\hline $\begin{array}{l}\text { Good (up to } \\
\text { 75\%) }\end{array}$ & $\begin{array}{l}\text { Statistical methods were attempted. } \\
\text { Most methods were applied but with } \\
\text { significant errors or omissions. }\end{array}$ \\
\hline
\end{tabular}




\begin{tabular}{|c|c|}
\hline & $\begin{array}{l}\text { The results are interpreted and } \\
\text { compared with literature values, but not } \\
\text { as fully as they might be. The } \\
\text { limitations and weaknesses are } \\
\text { discussed, but few or no suggestions are } \\
\text { made as to how to limit or eliminate } \\
\text { them. }\end{array}$ \\
\hline $\begin{array}{l}\text { Outstanding } \\
\text { (up to } 100 \%)\end{array}$ & $\begin{array}{l}\text { Statistical methods were fully and } \\
\text { properly applied. } \\
\text { The results are fully interpreted and } \\
\text { compared with literature values. The } \\
\text { limitations and weaknesses are } \\
\text { discussed and suggestions are made as } \\
\text { to how to limit or eliminate them. }\end{array}$ \\
\hline \multicolumn{2}{|c|}{$\begin{array}{l}\text { Rubrics parameter: Verification \& Conclusion } \\
\text { PI- code addressed: } 4.3 .4\end{array}$} \\
\hline $\begin{array}{l}\text { Inadequate } \\
\text { (up to } 25 \% \text { ) }\end{array}$ & $\begin{array}{l}\text { No model equation selected for } \\
\text { verification and conclusion were not } \\
\text { addressed. }\end{array}$ \\
\hline $\begin{array}{l}\text { Average (up } \\
\text { to } 50 \%)\end{array}$ & $\begin{array}{l}\text { Model equation selected is not } \\
\text { appropriate for verification and } \\
\text { conclusion of experiment is not clear } \\
\text { addressed. }\end{array}$ \\
\hline $\begin{array}{l}\text { Good (up to } \\
75 \%)\end{array}$ & $\begin{array}{l}\text { Model equation selected is appropriate } \\
\text { for verification and conclusion is not so } \\
\text { clear it should be. }\end{array}$ \\
\hline $\begin{array}{l}\text { Outstanding } \\
\text { (up to } 100 \% \text { ) }\end{array}$ & $\begin{array}{l}\text { Model equation selected is appropriate } \\
\text { for verification and conclusion is } \\
\text { clearly represented. }\end{array}$ \\
\hline \multicolumn{2}{|c|}{$\begin{array}{l}\text { Rubrics parameter: Write up of Journal } \\
\text { PI- code addressed: } 10.1 .2\end{array}$} \\
\hline $\begin{array}{l}\text { Inadequate } \\
\text { (up to } 25 \% \text { ) }\end{array}$ & $\begin{array}{l}\text { Report contains many mistakes, } \\
\text { making it difficult to follow and poorly } \\
\text { organized. Figures, tables and graph } \\
\text { are hard to understand, and are not } \\
\text { adequate to link to text. }\end{array}$ \\
\hline $\begin{array}{l}\text { Average (up } \\
\text { to } 50 \%)\end{array}$ & $\begin{array}{l}\text { Report is generally clear, but } \\
\text { distracting errors and flow make it } \\
\text { difficult to follow at times and } \\
\text { organization of report is weak. Figures, } \\
\text { tables and graph are hard to understand, } \\
\text { are not all linked to text. Needs } \\
\text { improvement. }\end{array}$ \\
\hline $\begin{array}{l}\text { Good (up to } \\
75 \%)\end{array}$ & $\begin{array}{l}\text { Report is logical and easy to read, and } \\
\text { may contain a few errors causing } \\
\text { minimal reader distraction and } \\
\text { organized strongly. All figures, tables } \\
\text { and graphs can be understood with } \\
\text { information given and are linked to } \\
\text { text. }\end{array}$ \\
\hline $\begin{array}{l}\text { Outstanding } \\
\text { (up to } 100 \% \text { ) }\end{array}$ & $\begin{array}{l}\text { Report is almost error-free, and } \\
\text { properly organized. All figures, tables } \\
\text { and graphs are easy to understand, and } \\
\text { are clearly linked to the text. }\end{array}$ \\
\hline \multicolumn{2}{|c|}{$\begin{array}{l}\text { Rubrics parameter: Following } S O P \\
\text { PI- code addressed: } 13.2 .2\end{array}$} \\
\hline $\begin{array}{l}\text { Inadequate } \\
(\text { up to } 25 \%)\end{array}$ & $\begin{array}{l}\text { Couldn't explain the steps of operating } \\
\text { the instruments. Unable to demonstrate }\end{array}$ \\
\hline
\end{tabular}

\begin{tabular}{|l|l|}
\hline & $\begin{array}{l}\text { the complete operation of the } \\
\text { instrument. }\end{array}$ \\
\hline $\begin{array}{l}\text { Average (up } \\
\text { to 50\%) }\end{array}$ & $\begin{array}{l}\text { Able to narrate the steps but was unable } \\
\text { to properly operate the instrument. }\end{array}$ \\
\hline $\begin{array}{l}\text { Good (up to } \\
\mathbf{7 5 \%})\end{array}$ & $\begin{array}{l}\text { Just able to explain all the steps } \\
\text { regarding SOP. Demonstrated the } \\
\text { working of the instruments. }\end{array}$ \\
\hline $\begin{array}{l}\text { Outstanding } \\
\text { (up to 100\%) }\end{array}$ & $\begin{array}{l}\text { Able to narrate all the steps in detail } \\
\text { regarding the SOP of instruments. } \\
\text { Demonstrated the operating the } \\
\text { instruments. }\end{array}$ \\
\hline
\end{tabular}

\section{B. Experimental frame work}

Bioprocess control laboratory experiments were performed under the frame work of Statistical Modeling and Hypothesis Testing for reinforcement of Model Validation Concepts and are listed in Table 2.

Table 2. List of experiments performed under this frame work

\begin{tabular}{|c|c|c|c|}
\hline $\begin{array}{l}\text { Sl. } \\
\text { No }\end{array}$ & $\begin{array}{l}\text { Objective of } \\
\text { Experiment }\end{array}$ & $\begin{array}{l}\text { Learning } \\
\text { Outcome of } \\
\text { experiment }\end{array}$ & $\begin{array}{l}\text { Statistical } \\
\text { Analysis } \\
\text { Involved }\end{array}$ \\
\hline 1 & $\begin{array}{l}\text { - Study the } \\
\text { dynamic } \\
\text { response of } \\
\text { first order } \\
\text { system (Liquid } \\
\text { Level System/ } \\
\text { Mercury } \\
\text { Thermometer } \\
\text { system) system } \\
\text { for } \\
\text { (i) step input } \\
\text { (ii) impulse } \\
\text { input } \\
\text { - Observe the } \\
\text { behaviour of } \\
\text { First Order } \\
\text { System (Liquid } \\
\text { Level System) } \\
\text { for Linearity. }\end{array}$ & $\begin{array}{l}\text { i)Comparison of } \\
\text { predicted } \\
\text { response with } \\
\text { experimental } \\
\text { observations for } \\
\text { step \& Impulse } \\
\text { inputs. } \\
\text { ii) Analysis of } \\
\text { data and } \\
\text { interpretation } \\
\text { the results. } \\
\text { iii)Identification } \\
\text { of system as } \\
\text { Linear or Non- } \\
\text { Linear, of } \\
\text { Importance of } \\
\text { Linearization \& } \\
\text { its limitations. }\end{array}$ & $\begin{array}{l}\text { Model } \\
\text { Prediction, } \\
\text { Chi Square } \\
\text { Test for } \\
\text { Goodness } \\
\text { of fit, } \\
\text { Model } \\
\text { validation. } \\
\text { Regression } \\
\text { Analysis, }\end{array}$ \\
\hline 2 & $\begin{array}{l}\text { - Study the } \\
\text { dynamic } \\
\text { response of } \\
\text { first order } \\
\text { systems } \\
\text { arranged in } \\
\text { Non- } \\
\text { interacting } \\
\text { mode for } \\
\text { (i) step input. } \\
\text { (ii) Impulse } \\
\text { input }\end{array}$ & $\begin{array}{l}\text { i)Comparison of } \\
\text { predicted } \\
\text { response with } \\
\text { experimental } \\
\text { observations } \\
\text { ii)Analysis of } \\
\text { data and } \\
\text { interpretation } \\
\text { the results. }\end{array}$ & $\begin{array}{l}\text { Model } \\
\text { Prediction, } \\
\text { Chi Square } \\
\text { Test for } \\
\text { Goodness } \\
\text { of fit, } \\
\text { Model } \\
\text { validation. }\end{array}$ \\
\hline 3 & $\begin{array}{lr}\text { - Study } & \text { the } \\
\text { dynamic } & \\
\text { response } & \text { of } \\
\text { first } & \text { order }\end{array}$ & $\begin{array}{l}\text { Comparison of } \\
\text { predicted } \\
\text { response with }\end{array}$ & $\begin{array}{l}\text { Model } \\
\text { Prediction, } \\
\text { Chi Square } \\
\text { Test for }\end{array}$ \\
\hline
\end{tabular}




\begin{tabular}{|l|l|l|l|}
\hline & $\begin{array}{l}\text { systems } \\
\text { arranged in } \\
\text { Interacting } \\
\text { mode for } \\
\text { (i) step input } \\
\text { (ii) impulse } \\
\text { input }\end{array}$ & $\begin{array}{l}\text { experimental } \\
\text { observations } \\
\text { ii)Analysis of } \\
\text { data and }\end{array}$ & $\begin{array}{l}\text { Goodness } \\
\text { of } \\
\text { interpretation } \\
\text { the results. }\end{array}$ \\
validation. \\
\end{tabular}

C. Implementation of experiments

All the experiments listed in the Table- 2 were performed under this frame work. As an illustration one experiment of structured enquiry type is presented here (Donald R. Coughanowr. et al.,2009).

Title of the Experiment: Dynamic Response of first order system.

Objective-1: Dynamic Response of first order system for Step Input using Single Tank Liquid level system.

Description of Experimental Set-up: The set-up is designed to study dynamic response of single and multi-capacity processes when connected in Interacting and non-Interacting mode. It is combined to study 1) Single capacity process 2) Non-interacting process and 3) Interacting process for various kinds of standard Inputs. The observed step response of the tank level in different mode can be compared with mathematically predicted response. Setup consists of supply tank, pump for water circulation, rotameter for flow measurement, transparent tanks with graduated scales, which can be connected, in Interacting and Non-Interacting mode.

Experimental Procedure:

- Experimental Set-up (Figure 2) is switched on and the flowrate was suitably adjusted using rotameter.

- System was allowed to attain steady state, so that the level in the process tank-1 attains steady state value. The initial steady state level of tank-1 was noted.

- The system was subjected to step input by increasing the input flowrate by certain magnitude say $10 \mathrm{LPH}$.

- Variation in level of tank-1 was noted until it reaches another steady state.

- $\mathrm{H}(\mathrm{t})$ Observed and $\mathrm{H}(\mathrm{t})$ predicted were tabulated as shown in observation Table 3.

- Plot of H(t) Observed \& H (t) predicted as a function of time was plotted for comparison.

- Dynamic Response of first order system for step input was analyzed.

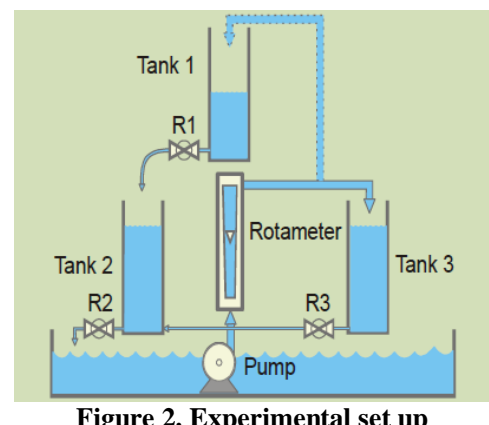

Figure 2. Experimental set up

Experimental Observations \& Tabulations:
- Inner diameter of tanks $=\mathrm{d}=92 \mathrm{~mm}$

- Area of the tank $=\mathrm{A} 1=\pi \mathrm{d}^{2} / 4$

- Initial flow rate $=30 \mathrm{LPH}$

$$
=6.647 \times 10^{-3} \mathrm{~m} 2
$$

- Initial steady state tank level $=36 \mathrm{~mm}$

- Final flow rate $=40 \mathrm{LPH}$

- Final steady state tank level $=72 \mathrm{~mm}$

Table 3. Observed and Predicted level for single tank system

\begin{tabular}{|c|c|c|}
\hline $\begin{array}{c}\text { Time } \\
(\mathbf{s e c})\end{array}$ & $\begin{array}{c}\text { Observed } \\
\text { Level } \\
(\mathbf{m m})\end{array}$ & $\begin{array}{c}\text { Predicted } \\
\text { Level } \\
(\mathbf{m m})\end{array}$ \\
\hline 0 & 36 & 36.00 \\
\hline 15 & 42 & 41.75 \\
\hline 30 & 46 & 46.58 \\
\hline 45 & 50 & 50.65 \\
\hline 60 & 54 & 54.06 \\
\hline 75 & 56 & 56.92 \\
\hline 90 & 58 & 59.33 \\
\hline 105 & 61 & 61.36 \\
\hline 120 & 63 & 63.06 \\
\hline 135 & 64 & 64.49 \\
\hline 150 & 65 & 65.69 \\
\hline 165 & 66 & 66.70 \\
\hline 180 & 67 & 67.54 \\
\hline 195 & 68 & 68.26 \\
\hline 210 & 69 & 68.85 \\
\hline 225 & 69 & 69.36 \\
\hline 240 & 69 & 69.78 \\
\hline
\end{tabular}

Sample Calculations:

- $\quad \mathrm{H}(\mathrm{t})_{\text {Observed }}=($ Level at time ' $\mathrm{t}$ ' - Level at time ' 0 ' $)$

$$
\text { = --- } \mathrm{m}
$$

- $\quad \mathrm{H}(\mathrm{t})$ Predicted $=\mathrm{AR}\left(1-\mathrm{e}^{-\mathrm{t} / \tau}\right)$

- $A=$ Magnitude of step input $=---\mathrm{m}^{3} / \mathrm{s}$

- $\quad \mathrm{R}=$ Valve resistance $=----\mathrm{s} / \mathrm{m}^{2}$

- Time constant of the first order system is

$$
\tau=\mathrm{A}_{1} \mathrm{R}
$$

where, $A_{1}$ is area of the tank and $R$ is valve Resistance

Experimental Result:

The analysis of dynamic response of first order system for step input was performed. Comparison of predicted response with experimental observations for step Input was done. The possible reasons for deviations between experimentally observed and theoretically predicted responses were studied. Further the significance of Assumptions during modeling on prediction of response was studied.

Chi-square goodness of fit test was performed to test the null hypothesis that the observed values of the experiment follow 
theoretical values. The observed value of Chi-square was $\chi^{2}=0.0984$ The critical value was $\chi_{0.05,16}^{2}=26.296$ with $\alpha=0.05$ and 16 degrees of freedom. Since $\chi^{2}<\chi_{0.05,16}^{2}$ the null hypothesis was accepted at $5 \%$ level of significance. Hence it can be inferred that the theoretical values were in line with observed values. Model validation was done to check the adequacy of the model (Douglas Montgomery et al., 2014; Ryoungsun P. 2018; Wendy, J. et al,2014).

Objective-2: Observe the behaviour of First Order System (Liquid Level System) for Linearity.

\section{Experimental Procedure:}

- Experimental Set-up is switched on and the flowrate was suitably adjusted (say 20LPH) using rotameter.

- System was allowed to attain steady state, so that the level in the process tank-1 attains steady state value. The corresponding steady state level of tank-1 was noted.

- Then the flowrate was increased to suitable value (say $30 \mathrm{LPH}$ ) using rotameter. The system was allowed to attain steady state and note down the steady state level of liquid in the tank-1. Repeat the experiment for several input flow rates and note down the corresponding steady state levels.

- system was subjected to step input by increasing the input flowrate by certain magnitude say 10LPH.

- Note down the Q (Flow rate) and corresponding steady state Q (Level) as shown in Table 4.

- Perform Regression analysis was to understand the behaviour of System for Linearity (Linear or NonLinear System).

- Comment on the result.

Table 4. Steady state level for various flow rates

\begin{tabular}{|l|l|l|l|l|l|l|l|l|l|}
\hline $\begin{array}{l}\text { Flow } \\
\text { Rate- } \\
\text { Q(LPH) }\end{array}$ & 20 & 30 & 40 & 50 & 60 & 70 & 80 & 90 & 100 \\
\hline $\begin{array}{l}\text { Level- } \\
\text { H(mm) }\end{array}$ & 18 & 32 & 49 & 63 & 70 & 80 & 86 & 92 & 95 \\
\hline
\end{tabular}

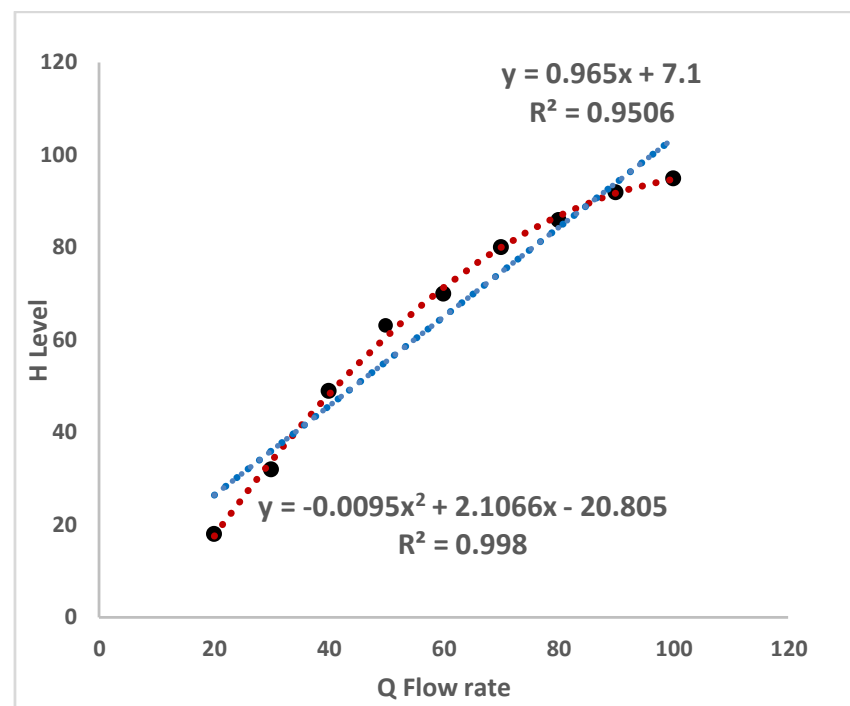

Figure 3. Plot of steady state Level (H) versus Flowrate (Q) for Liquid Level System

Experimental Result:

The system was analyzed for linearity. It was observed that system is Non-Linear in nature as evident by $\mathrm{R}^{2}$ value of 0.998 , however even the liner fit also showed the $\mathrm{R}^{2}$ value of 0.9506 which indicates that, even the Linear approximation can also be done to develop the mathematical model and predict response (Refer Figure 3). Linearization involves creating a linear approximation of a non-linear system that is valid in a small region of steady state around which the system operates. The central idea of linear approximation technique is to transform non-linear system dynamics into linear system so that the conventional linear techniques can be applied. The mathematical models that are best able to analyze and study are linear ones (Douglas Montgomery et al., 2014; Xiangshun Li, et al.,2018).

Similar approach of study of dynamic response of different systems for various kinds of inputs was performed for all other experiments listed in Table 2. In all these experiments it was observed that theoretical values were in line with observed values when tested for goodness of fit.

\section{Student Feed Back}

A formal anonymous feedback was taken from students to identify the gaps and scope for further improvement in learning curve. Sample copy of feedback form is shown in Table-5.

The feedback questionnaire on the scale of 0-10 for each question was framed, with ' 0 ' being the lowest level of satisfaction and ' 10 ' being the highest level of satisfaction. The number of students participated in the survey was 42 .

Table 5. Questionnaire for student Feedback

\begin{tabular}{|l|l|l|}
\hline Sl. & Questions & $\begin{array}{l}\text { Score } \\
(0-10)\end{array}$ \\
No & & \\
\hline
\end{tabular}




\begin{tabular}{|l|l|}
\hline 1 & $\begin{array}{l}\text { Implementation of statistical module in } \\
\text { Bioprocess Control Laboratory, improved } \\
\text { the ability of analysis \& interpretation of } \\
\text { data, and synthesis of information to } \\
\text { provide valid conclusions? }\end{array}$ \\
\hline 2 & $\begin{array}{l}\text { Application of Statistical Modeling and } \\
\text { Hypothesis Testing was helpful to } \\
\text { reinforce Model Validation Concepts in } \\
\text { Bioprocess Control Laboratory. }\end{array}$ \\
\hline 3 & $\begin{array}{l}\text { The experiments performed in Bioprocess } \\
\text { Control Laboratory strengthened the } \\
\text { domain knowledge. }\end{array}$ \\
\hline 4 & $\begin{array}{l}\text { Training module was helpful in smooth } \\
\text { execution of the laboratory. }\end{array}$ \\
\hline 5 & $\begin{array}{l}\text { The categorization Bioprocess Control } \\
\text { Laboratory into- } \\
\text { demonstration, experiments } \\
\text { enquiry and open-ended experiments was } \\
\text { helpful in strengthening the ability to } \\
\text { design, conduct experiments, as well as } \\
\text { analyze and interpret data. }\end{array}$ \\
\hline 6 & $\begin{array}{l}\text { Adequate proficiency of Good Laboratory } \\
\text { Practices (GLP) and Standard Operating } \\
\text { Procedure (SOP) was obtained during the } \\
\text { execution of this Laboratory. }\end{array}$ \\
\hline 7 & $\begin{array}{l}\text { The activity helped in improving the } \\
\text { verbal and written communication skills. }\end{array}$ \\
\hline
\end{tabular}

\section{Results}

The implementation of statistical frame work in Bio Process Control laboratory aimed at strengthening of domain knowledge and analysis, interpretation \& decision-making skills was instrumental in addressing some of the program Outcomes (POs).

The attainment of Program Outcomes (PO) was evaluated by mapping the rubrics parameter with Performance Indicator (PI) as shown in the Table-6.

Table 6. Mapping of Rubric Parameters with Performance Indicators

\begin{tabular}{|c|c|c|}
\hline $\begin{array}{c}\text { Graduate } \\
\text { Attribute \& } \\
\text { Program } \\
\text { Outcome }\end{array}$ & $\begin{array}{c}\text { Rubrics } \\
\text { Parameters }\end{array}$ & PI Addressed \\
\hline \multirow{3}{*}{$\begin{array}{l}\text { GA: } \\
\text { Conduct } \\
\text { Investigatio } \\
\text { ns } \\
\text { complex } \\
\text { problems. } \\
\text { PO-4: } \\
\text { An ability to } \\
\text { design \& } \\
\text { conduct } \\
\text { experiments, } \\
\text { as well as }\end{array}$} & $\begin{array}{l}\text { Identification of } \\
\text { Problem/ } \\
\text { parameter }\end{array}$ & $\begin{array}{l}\text { 4.1.1: Define } \\
\text { problem to carry-out } \\
\text { investigation with its } \\
\text { scope and importance. }\end{array}$ \\
\hline & $\begin{array}{l}\text { Selection of } \\
\text { appropriate } \\
\text { procedure }\end{array}$ & $\begin{array}{l}\text { 4.1.2: Identify and } \\
\text { apply relevant } \\
\text { experimental } \\
\text { procedure for } \\
\text { defined problem }\end{array}$ \\
\hline & $\begin{array}{l}\text { Conduct of } \\
\text { experiment }\end{array}$ & $\begin{array}{l}\text { 4.1.3: Use appropriate } \\
\text { analytical instruments } \\
\text { to carry-out the } \\
\text { experiments }\end{array}$ \\
\hline
\end{tabular}

\begin{tabular}{|c|c|c|}
\hline \multirow[t]{4}{*}{$\begin{array}{l}\text { analyze } \\
\text { data. }\end{array}$} & $\begin{array}{l}\text { Data Collection } \\
\& \\
\text { representation }\end{array}$ & $\begin{array}{l}\text { 4.3.1: Use appropriate } \\
\text { procedures, tools and } \\
\text { techniques to collect } \\
\text { and analyze data }\end{array}$ \\
\hline & Analysis of data & $\begin{array}{l}\text { 4.3.2: Critically } \\
\text { analyze data for trends } \\
\text { and correlations, } \\
\text { stating possible errors } \\
\text { and limitations. }\end{array}$ \\
\hline & $\begin{array}{l}\text { Interpretation of } \\
\text { data }\end{array}$ & $\begin{array}{l}\text { 4.1.4: Correlate the } \\
\text { experimental } \\
\text { outcomes } \\
\text { underlying theoretical } \\
\text { concepts } \\
\text { principles }\end{array}$ \\
\hline & Conclusion & $\begin{array}{l}\text { 4.3.4: Synthesize } \\
\text { information and } \\
\text { knowledge about the } \\
\text { problem from the raw } \\
\text { data to reach } \\
\text { appropriate } \\
\text { conclusions }\end{array}$ \\
\hline $\begin{array}{l}\text { GA: } \\
\text { Communicat } \\
\text { ion } \\
\text { PO-10: } \\
\text { An ability to } \\
\text { communicat } \\
\text { e effectively. }\end{array}$ & $\begin{array}{l}\text { Journal Write } \\
\text { up }\end{array}$ & $\begin{array}{l}\text { 10.1.2: Produce clear, } \\
\text { well-constructed, and } \\
\text { well-supported } \\
\text { written engineering } \\
\text { documents. }\end{array}$ \\
\hline $\begin{array}{l}\text { PSO-13 } \\
\text { Program } \\
\text { Specific } \\
\text { Outcome }\end{array}$ & $\begin{array}{l}\text { Following SOP } \\
\text { \& GLP }\end{array}$ & $\begin{array}{lr}\text { 13.2.2: } & \text { Follow } \\
\text { standard } & \text { operating } \\
\text { procedures } & \text { adhering } \\
\text { to } & \text { laboratory } \\
\text { guidelines. } & \\
\end{array}$ \\
\hline
\end{tabular}

The attainment of various PI's on a scale of 1 to 10 was measured and represented in Figure 4.

The attainment for design \& conduct of experiments, as well as analyse and interpret data (PO-4) was good. However, there is scope for improvement in the area of Communication (PO-10) and follow of SOP \& GLP (PSO13).

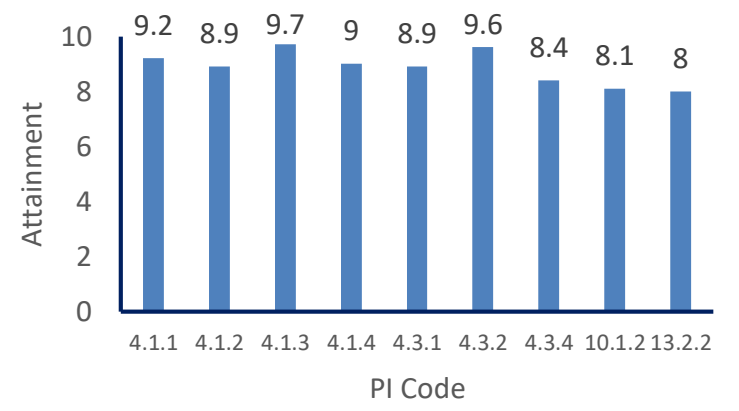

Figure. 4. Attainment of program outcomes and performance indicators

A formal anonymous feedback of the students was collected to identify the gaps and scope for further improvement. The 
results of the feedback survey are shown in Figure 5. The feedback of the students revealed that the frame work of Statistical Modeling and Hypothesis Testing for reinforcement of Model Validation Concepts in Bio-Process Control Laboratory was very helpful in enhancing the domain skill-sets and gave them experiential learning. However, there is scope for improvement in the area SOP \& GLP and communication Skills which need to be further improved in the next cycle.

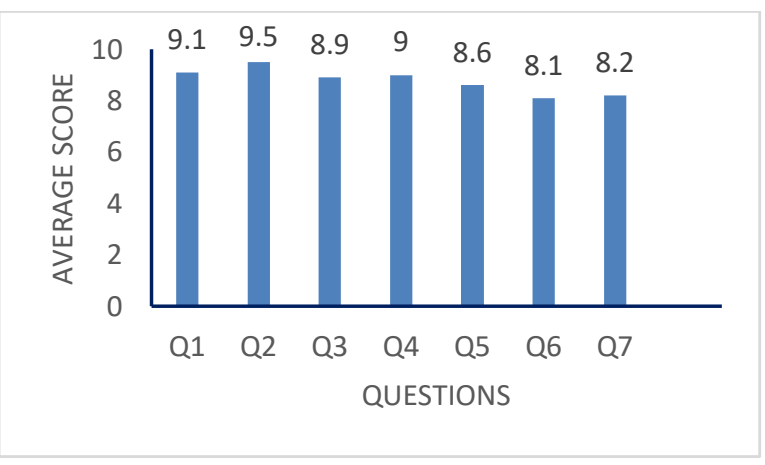

Figure 5. Students feedback

The feedback of the students revealed that the implementation of statistics gave them experiential learning. The students expressed satisfaction in terms of having acquired the in-depth knowledge of statistical concepts such as Correlation, Regression, Hypothesis testing, model validation and their applications in the field of Control Engineering.

\section{Conclusions}

From our experience of implementing frame work of Statistical Modeling and Hypothesis Testing for reinforcement of Model Validation Concepts in Bio-Process Control Laboratory, we conclude that the students successfully demonstrated their ability in choosing proper statistical tools for analysis \& interpretation of data to draw meaningful conclusion, formulating hypothesis, testing procedures, model prediction and model validation. Attainment of PI shows scope for improvement in the area of Communication (PI 10.1.2) and Following SOP \& GLP (PI 13.2.2). Bio-Process Control Laboratory at VI semester is being implemented with this frame work complement the skill-sets needed for a Biotechnology graduate.

\section{Acknowledgment}

The authors thank Dr.Ashok Shettar, Honorable ViceChancellor, KLE Technological University, Dr. N.H.Ayachit, Registrar, KLE Technological University and Dr.B.S.Hungund, Head, Department of Biotechnology, KLE Technological University, Hubballi for their constant encouragement and support.

\section{References}

Anil Shet, Basavaraj Hungund, Deepak Y, Gururaj T, Laxmikant Patil, Sharanappa A, Shivalingsarj yDesai, Uday M, Veeresh Hombalimath and Zabin B. (2017) Theme-based Minor Project Implementation for Basic Skill Enhancement in Biotechnology. Journal of Engineering Education Transformations, Volume 30, No. 4, 78-83. ISSN 2349-2473, eISSN 2394-1707.
Dahms, A.S. and Bourque, J. (2001) Careers in the biotechnology industry: what do our students do in the industry and what degrees and training are necessary? Biochemistry and Molecular Biology Education, Vol. 39, 257-261.

Donald R. Coughanowr. Steven E. LeBlanc. (2009) Process

Systems Analysis and Control. Published by McGraw-Hill chemical engineering series. 3rd ed. 602 pp. ISBN 978-0-07339789-4

Douglas Montgomery, George Runger. (2014) Applied Statistics and Probability for Engineers, John Wiley, 6th ed. ISBN: 978-1118-74395-9

Eutimio Gustavo Fernandez, Rodolfo Veliz, Bruno Labate Vale da Costa, Alexandre Goncalves de Rezende and Aldo Tonso. (2013) Using Statistical Tools for Improving Bioprocesses; Asian Journal of Biotechnology; 5(1),1- 20.

Kwang-Min Lee and David F. Gilmore (2006) Statistical Experimental Design for Bioprocess Modeling and Optimization Analysis; Applied Biochemistry and Biotechnology, Vol 135, 101 115.

Romero, R. Ferrer, A. Capilla, C. Zunica, L. Balasch, V. Serra \& R. Alcover (1995) Journal of Statistics Education. Teaching Statistics to Engineers: An Innovative Pedagogical Experience. 3:1, DOI: 10.1080/10691898.1995.11910481

Ryoungsun P. (2018). Practical Teaching Strategies for Hypothesis Testing. The American Statistician, DOI: 10.1080/00031305.2018.1424034

Sharanappa Achappa, L.R.Patil, V.S.Hombalimath, Anil R. Shet. (2020). Implementation of Project-Based-Learning (PBL) Approach for Bioinformatics Laboratory Course. Journal of Engineering Education Transformations, Volume 33,247-252. Special issue, eISSN 2394-1707.

Sharanappa,A. Patil, L .R. Hombalimath, V.S. Deepak Y, Anil R Shet (2018) Application of Statistics in Bioprocess Engineering Laboratory to Reinforce Students' Ability in Data Collection, Analysis and Interpretation; Journal of Engineering Education Transformations; Special Issue.1-6. eISSN 2394-1707.

Sharanappa A, L.R.Patil, V.S.Hombalimath, Anil Shet (2020) Implementation of Project-Based-Learning (PBL)Approach for Bioinformatics Laboratory Course. Journal of Engineering Education Transformations, Volume 33, 247-252. Special issue, eISSN 2394-1707.

Stevens. D.D \& A.J.Levi.(2005). Introduction to Rubrics: An Assessment Tool to Save Grading Time, Convey Effective Feedback and Promote Student Learning. Sterling, Virginia: Stylus Publishing.

Wendy J. Post and Marijtje A.J. van Duijn. (2014) Teaching Hypothesis Testing: A Necessary Challenge. Sustainability in statistics education. Proceedings of the Ninth International Conference on Teaching Statistics (ICOTS9), Flagstaff, Arizona, USA. Voorburg, The Netherlands: International Statistical Institute. iase-web.org

Xiangshun Li, Zhiang Li. (2018) The Application of Linear and Nonlinear Water Tanks Case Study in Teaching of Process Control.IOP Conf. Series: Earth and Environmental Science. doi :10.1088/1755-1315/113/1/012165.

Zaiton Haron, Shahrin Mohammad, Abdul Rahman Mohd Sam, Mushairry Mustaffar, Jamaludin Mohd Yatim (2013) The Implementation of an Open-Ended Experiment in the Civil Engineering Laboratory. Procedia - Social and Behavioral Sciences $102,548-559$. 